\title{
Entrepreneurship Education and Its Effect on Entrepreneurial Intentions of Omani Undergraduate Students
}

\author{
Fatima Al Ghafri ${ }^{1^{*}}$ and Dr. Mustafa Malik ${ }^{1^{*}}$ \\ ${ }^{1}$ Department of Management College of Economics, Management and Information Systems, University of Nizwa, Oman
}

\begin{abstract}
Entrepreneurial capacity building is one of the important strategies to boost economic growth in general and solve unemployment problems in particular. Governments across the world have taken wider initiatives to encourage entrepreneurship among younger generations. Oman has never been an exception to this phenomenon. It has introduced several initiative and programs to promote entrepreneurship in the Country. One of the important initiatives to promote entrepreneurship came in the year 2015 when the Oman Ministry of Higher Education made it mandatory for all the higher education institution (HEIs) in the Country to introduce a course on Entrepreneurship across all their academic programs. Since the academic year 2015-2016, all the HEIs in the country have been training all their students in entrepreneurship as a national requirement. In this background, the purpose of this paper is to report the effects of entrepreneurship education, which is a national initiative, on the students' entrepreneurial intention at the Country's second biggest university, the University of Nizwa. One full cohort of students $(\mathrm{N}=349)$ who registered for the University required Entrepreneurship course (MNGT100) at the University of Nizwa, for Fall 2019-2020 Semester was surveyed. The findings show that the entrepreneurial education can positively influence the entrepreneurial intentions of the students. The findings have academic as well as policy implications as strengthening and enhancing entrepreneurship education will further enhance the students' entrepreneurial intentions.
\end{abstract}

\section{Introduction}

Oman has been a country where innovation driven small family business existed throughout its history. The business skills are passed down over generations, from the parents to their children, while helping their parents in their day-to-day business activities (one of the author's learnt this during an interaction with the Vice Chancellors of his University, who is Omani and has developed business acumen from his father during his childhood). A study by AlMaimani and Johari (2015) indicated that while majority of business owners in Oman had previous work experiences, more than $80 \%$ among them had no formal business training. While there is no denying to the fact that the entrepreneurial education will enhance the entrepreneurial skills of the students, the fact that there are numerous examples of successful entrepreneurs in the Country, who did not attend any formal entrepreneurship training, brings about a question as to whether the formal entrepreneurship education influences the students' intentions to become entrepreneurs. Yet the same study (AlMaimani and Johari, 2015) found that major obstacles faced by small business owners in Oman are, the lack of essential knowledge of trade and the lack of important business skills which no doubt signifies the importance of entrepreneurship education.

While entrepreneurship as a concept is not new (Bann, 2009), it has lately been aggressively promoted by the countries across the world to help them to reduce unemployment. Many countries have repositioned resources to facilitate, support and encourage entrepreneurship. Ramalan and Ngah (2012) argue that the international economy and also the international labor market are unstable and this requires a need for emphasis on entrepreneurship which is supposed to help economies in creating sustainable jobs. El-Gohary, O'Leary and Radway (2012), in their study argued that both developed and developing economies need to have more entrepreneurs who are willing to assist the economic growth. This is supported by Olorundare \& Kayode, (2014) who argue that entrepreneurship activities have positive impact on national GDP and reducing unemployment rates.

\footnotetext{
*Corresponding author: ${ }^{1}$ alghafrifs88@gmail.com, ${ }^{2}$ mustafamalik@unizwa.edu.om
} 
Lately, almost every country in the world is fostering the growth of SMEs. Oman is one of those countries that is concentrating on entrepreneurship to drive the economic development in general and solve the unemployment problem in particular. In 2013, his Majesty Sultan Qaboos emphasized the importance of entrepreneurship in developing the country, reducing the unemployment and reduce the dependency on oil resources (Ashrafi \& Murtaza, 2010), which lead to the introduction of various national level initiatives to promote entrepreneurship in the Country.

The younger generation is usually the target to promote entrepreneurial capacity building across the world. Lekhanya, (2016) argues that the significance of raising the entrepreneurial intentions amongst the young people helps to reduce poverty and creates chances for increased employment. One of the niche targets among the youth is the students in the higher education institutions who make up the largest proportion of society. Young graduates with motivation and intention to become future entrepreneurs have been seen as one of the targets to tap on and Oman has not been aversed to it. Therefore, in 2015 the Ministry of Higher Education in Oman introduced a mandatory course (module) on Entrepreneurship to be compulsorily taught to all the students, irrespective of their major of studies, in all higher education instructions across the country. It is in this perspective the present study has been conducted to investigate the impact of entrepreneurship education (EI) on the students' entrepreneurial intention (SEI).

\section{Literature Review}

Existing literature is by and large in favor of the understanding that entrepreneurial education has a positive impact on entrepreneurial intentions of the university students (Malebana and Swanepoel, 2014; Sánchez 2011; Hussain and Norashidah, 2015). This understanding has led to the introduction of entrepreneurship education in the higher education curricula to enhance entrepreneurial attitudes and abilities of the university students. While traditional business education emphasizes the establishment and operation of large enterprises, the entrepreneurship programs emphasize creativity, imagination, proactiveness, and risk taking that can respond to an uncertain environment (Jones and English, 2004). While Zhang et al. (2014) found that entrepreneurship education, perceived desirability, and entrepreneurial self-efficacy are positively related to the students' entrepreneurial intentions, Sánchez (2011) and Naktiyok et.al (2010) found that students who studied entrepreneurship have increased intention towards self-employment than those who did not.

Many studies have been conducted to explore students' attitudes towards entrepreneurship in the Oman context (such as Segumpan and Zahari, 2012; Al-Harrasi and Al-Salti, 2014; Amma and Fahad, 2013; Bakheet, 2018). While many of these studies showed that the students in Oman had a positive attitude towards entrepreneurship, studies such as Ibrahim et al., (2017) showed the students in Oman had a low or no intention to choose entrepreneurship as their career. Yet a study by Bakheet (2018) revealed a strong positive relationship between attitudes and intentions among Omani students towards entrepreneurship. Since the studies conducted in Oman has shown mixed results, and also none of these studies has studied students' entrepreneurial intentions after studying a course on entrepreneurship, necessitates conducting a study that aims to find answer to the question, as to whether or not studying a course in entrepreneurship has any effect on students' entrepreneurship intentions.

\subsection{Entrepreneurship Education}

Education, especially entrepreneurial education, is a major basis for economic prosperity. Over the last few decades entrepreneurship education has been introduced in the educational programs at all levels from schools to the universities. Many empirical studies have shown that entrepreneurship can be encouraged through entrepreneurship education (Wang \& Verzart, 2011). This signifies the importance of teaching entrepreneurship in schools and universities in orienting younger generations towards entrepreneurship. The entrepreneurship education has been defined by Young (1997) as the structured formal conveyance of entrepreneurial knowledge, which can further be described as the concepts, skills and mentality required by enterprise managers or owners (Anderson, 2008). It is a means to make students capable of choosing entrepreneurship as their career by instilling the skills to be creative, innovative, and develop other entrepreneurial behaviors. One of the main methods to spread entrepreneurship amongst the most productive population (the youth) is via entrepreneurial education (Greene et al., 2015). Entrepreneurship education can transfer concepts into practices and lead students to think about entrepreneurship as a career (Fayolle \& Gailly, 2013). While Keat, Selvarajah, \& Meyer (2011) opine that entrepreneurship education increases the tendency of students towards entrepreneurship, Kalyoncuoğlu et al. (2017) argues that exposure to entrepreneurial education increases the students' intentions to become entrepreneurs. Entrepreneurship education is therefore very necessary to educate students about entrepreneurship, give them the chance to know what the market needs, and what are the opportunities available to learn the needed skills related to that (Welsh et al., 2016).

\subsection{Entrepreneurial Intentions}

Intentions mean what people plan to do or to be in future. Influencing students' intentions positively towards entrepreneurship is essential, as entrepreneurial intentions play significant role in entrepreneurial actions (Lee, Wong, Foo, \& Leung, 2011). 
Therefore, educational systems have to focus on how it develops students' intentions to be entrepreneurs. According to Fretschner and Weber, (2013) there are several programs in the universities to inspire students about entrepreneurship and preparing them with required skills. There is a significant relationship between having entrepreneurship education and intentions. For example, a study by Gerba (2012) showed students who have undergone entrepreneurial education have higher entrepreneurial intentions in comparison to those who had no exposure to the entrepreneurial education. Students who have studied entrepreneurship can understand its importance. They are influenced by education that changes their intentions and perceptions toward entrepreneurship. According to Ajzen (1991), the intention to pursue entrepreneurship as a career is reflected through students behavioral factors like; perceived desirability, propensity to act, and perceived feasibility. Recognizing persons with the intention to start a business might help the government in guiding and supporting them in job creation (Douglas, 2013).

\subsection{Perceived Desirability and Perceived Feasibility}

Entrepreneurial intentions can be influenced by perceived desirability and feasibility of entrepreneurship. Factors such as entrepreneurial activity effect perceptions of desirability and feasibility that leads to change in the intentions toward entrepreneurial behavior (Krueger, 1993). For instance, perceived feasibility shows the opinions of a personal ability to do a certain task (Bandura, 1995). Nevertheless, even with the complicated tasks, people will be comfortable to do it if they feel that they are able to do it and will take action accordingly (Krueger, Hansen, Michl \& Welsh, 2011). Sesen (2013) found a significant relationship between perceived feasibility (self-efficacy) and entrepreneurial intentions. According to Malebana and Swanepoel (2014), entrepreneurial self-efficacy is derived from entrepreneurship education. Then, by education, the students' perceived feasibility might modify to impact positively on entrepreneurial intentions. Students who were exposed to entrepreneurship education have more abilities and skills to be entrepreneurs. They believe that they are more capable to pursue entrepreneurship.

On the other side, perceived desirability relates to one's imagination of having his/her own business as attractive (Krueger, 1993). According to Veciana et al. (2005), desirability has positive relationship with entrepreneurial intention; no doubt desirability to be an entrepreneur can be influenced by family, culture, colleagues and others (Shapero et al., 1982). Thus, desire to become an entrepreneur may be due to being influenced by family members who have experience in the field or being affected by surrounding people, such as peers. However, education can influence the students' desirability toward entrepreneurship through motivation and skills. Therefore, their perceived desirability will affect positively on entrepreneurial intention.

\subsection{Theoretical Framework}

While there is no universal consensus on the definitions of entrepreneurship, there is an agreement that it is the process entailing recognition of a need, exploiting an opportunity to fulfil the need and building an enterprise around it (Hattab, 2014), and that this behavior would be best predicted by the entrepreneurial intentions (Linan et al., 2011). This study has adapted Linan's Entrepreneurial Intention Model (Linan, 2004) presented in Figure 1. The variable government support has been added to the model based on factor analysis results.

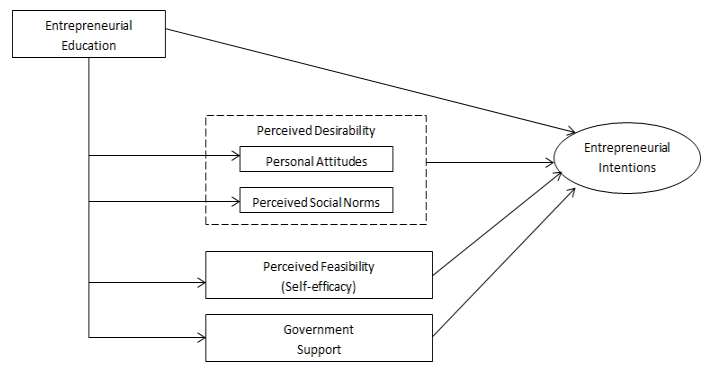

Fig. 1. Theoretical framework for the study

Source: developed for this study based on Linan's Entrepreneurial Intention Model (Linan, 2004)

\subsection{Hypotheses}

Based on the literature review and the theoretical framework for this study, hypotheses as shown in Table 1, were set for investigation. 
Table 1. Hypotheses

\begin{tabular}{ll}
\hline Hypothesis & Description \\
\hline H1a & $\begin{array}{l}\text { Entrepreneurial education has a positive } \\
\text { impact on students' entrepreneurial intentions. }\end{array}$ \\
& $\begin{array}{l}\text { Entrepreneurial education has a positive } \\
\text { impact on perceived desirability of } \\
\text { entrepreneurship. }\end{array}$ \\
H1c & $\begin{array}{l}\text { Entrepreneurial education has a positive } \\
\text { impact on perceived feasibility of }\end{array}$ \\
& entrepreneurship. \\
H1d & $\begin{array}{l}\text { Entrepreneurial education has a positive } \\
\text { impact on perceived government support for }\end{array}$ \\
& entrepreneurship. \\
H2a & $\begin{array}{l}\text { Students' higher perceived desirability of } \\
\text { entrepreneurship has positive influence on } \\
\text { their entrepreneurial intentions. }\end{array}$ \\
H2b & Students' higher perceived feasibility of \\
entrepreneurship has positive influence on \\
their entrepreneurial intentions. \\
Students higher perceived government \\
H2c & $\begin{array}{l}\text { support has positive influence on their } \\
\text { entrepreneurial intentions. }\end{array}$ \\
\hline
\end{tabular}

\section{Methodology}

\subsection{Sampling}

This study assesses the entrepreneurial intentions of undergraduate students who have been studying a special entrepreneurship course. All the students studying the University required course on Entrepreneurship (MNGT100) were targeted. The course is offered for 16 weeks. Students are taught basics of entrepreneurship and business plan preparation with a considerable exposure to the real-life entrepreneurs through case studies and guest lectures by entrepreneurs.

\subsection{Data Collection}

The study targeted all the students $(\mathrm{N}=349)$ studying dedicated University required Entrepreneurship courses (MNGT100). A total of 259 students participated in the questionnaire survey (participation rate $=72.14 \%$ ). All the 259 students who participated in the survey returned completely filled and usable questionnaires, thereby generating a response rate of $100 \%$.

Data were collected inside the classroom during the tutorial classes using a questionnaire designed to measure variables that have an impact on students' entrepreneurship intentions. The items were adapted (for example from Linan, 2004; Linan et al., 2011; Krueger, 1993) and modified to suit the local cultural and social norms. The questionnaire was originally developed in 'English language' and later translated to 'Arabic language' with the help of a professional translator. The Arabic questionnaire was used for the easy understanding of the questions by the participants. However, the participants were given a choice to use either language.

\subsection{Reliability Testing}

Before analysis of the data was carried out, reliability analysis was conducted using Cronbach's alpha. Table 2 presents the Cronbach's alpha for all constructs used in this study. 
Table 2. Reliability analysis of Personal Attitudes, Social Norms. Feasibility (self-efficacy), Government Support, Entrepreneurship Education, Intentions constructs for undergraduate students

Table 2. Reliability analysis of Personal Attitudes, Social Norms. Feasibility (self-efficacy), Government Support, Entrepreneurship Education, Intentions constructs for undergraduate students

\begin{tabular}{lcc}
\hline \multicolumn{1}{c}{ Construct } & $\begin{array}{c}\text { Number of } \\
\text { items }\end{array}$ & $\begin{array}{c}\text { Cronbach's } \\
\text { Alpha }\end{array}$ \\
\hline Personal Attitude & 5 & 0.589 \\
Social Norms & 6 & 0.711 \\
Feasibility (self-efficacy) & 6 & 0.773 \\
Government Support & 2 & 0.717 \\
Entrepreneurship Education & 8 & 0.893 \\
Intentions & 6 & 0.850 \\
\hline
\end{tabular}

The Cronbach's alpha for the constructs perceived social norms, feasibility, government support, and entrepreneurship education are $0.711,0.773,0.717,0.893$, and 0.850 respectively, which is good as alpha value greater than 0.7 is considered acceptable (George \& Mallery, 2003). Nevertheless, alpha value for personal attitudes construct is in the questionable range of below 0.6 .

\section{Results}

\subsection{Profile of Respondents}

A total of 259 complete and valid responses were received and were analyzed. 92.3 percent comprised of females and 5 percent comprised of males, where as 2.7 percent did not mention their gender. The male-female ratio of the respondents is consistent with the male-female student ratio of the University (which is nearly 10:90) where the study was conducted. The University where the study was conducted is comprised of four colleges namely College of Arts and Science (CAS), College of Economics, Management and Information Systems (CEMIS), College of Engineering and Architecture (CEA), and College of Nursing and Pharmacy (CPN). Out of the total 259 respondents $242(93.4 \%)$ mentioned their major of studies, whereas 17 $(6.6 \%)$ did not mention their major of studies. Out of those who mentioned their major of studies $(\mathrm{N}=242), 54.9$ percent represented the CAS, 26.2 percent CEMIS, 8.6 percent CEA, and 9.5 percent represented CPN. The representation of each college is again consistent with the share of the colleges in total number of students enrolled in the University. When asked whether they have ever thought of starting their own business in the past, 21.6 percent said 'yes', whereas 78.4 percent said 'No'. The respondents were asked if they are presently working or have ever worked in the past, 9.7 percent said 'yes', whereas 90.3 percent said 'no'. To check whether the respondents have any business background they were asked if their parents or a member in their family have their own business, 48.2 percent said 'yes', whereas 51.8 percent said 'no'.

Furthermore, the students across all the Colleges showed similar desire towards entrepreneurship (entrepreneurship intentions) nevertheless with varying means for different programs. For examples from the CPN, the Nursing major students (Mean EI=2.17) showed higher desire than Pharmacy major students (Mean EI=1.80). Similarly from CEMIS, the students with Business (Mean EI=2.02), Information systems (Mean EI=2.15) and Finance (Mean EI=2.25) showed higher desire for entrepreneurship than other majors such as Marketing, Tourism and Accounting. From CEA students of Chemical Engineering and Civil Engineering, with mean EI scores of 2.07 and 2.10 respectively, showed higher desire for entrepreneurship than students of Architecture Design. Finally from CAS the students of Biology (Mean EI=2.11), Environmental Sciences (Mean $\mathrm{EI}=2.0$ ), Mathematics (Mean $\mathrm{EI}=2.07$ and Statistics (Mean $\mathrm{EI}=2.07$ ) majors showed higher desire than other majors in the College.

One of the interesting factors was that the females (Mean $E I=2.0, N=239$ ) showed a higher desire for entrepreneurship than their counterpart males (Mean EI=1.73, N=12). While this is in consistent with other studies such Amma and Fahad (2013), this could also be because the participation of the female participants in this study is very high than the male participants. 


\subsection{Factor Analysis}

Factor analysis aims to explain correlations among variables as the result of one or more factors. It involves data reduction to represent a group of variables by a smaller number. In this study factor analysis was conducted to identify items and their dimensions. Six dimensions evolved through factor analysis using Varimax rotation for all 34 items. There are entrepreneurship education, entrepreneurial intention, perceived feasibility, perceived desirability, attitude toward entrepreneurship, and government support. 2 items from Attitudes dimension (AE1 and AE4) and 2 items Perceived social norms dimension (PSN5 and PSN6) were excluded from analysis. Table 2 presents the factor loading for each dimension.

Table 3. Results of factor analysis

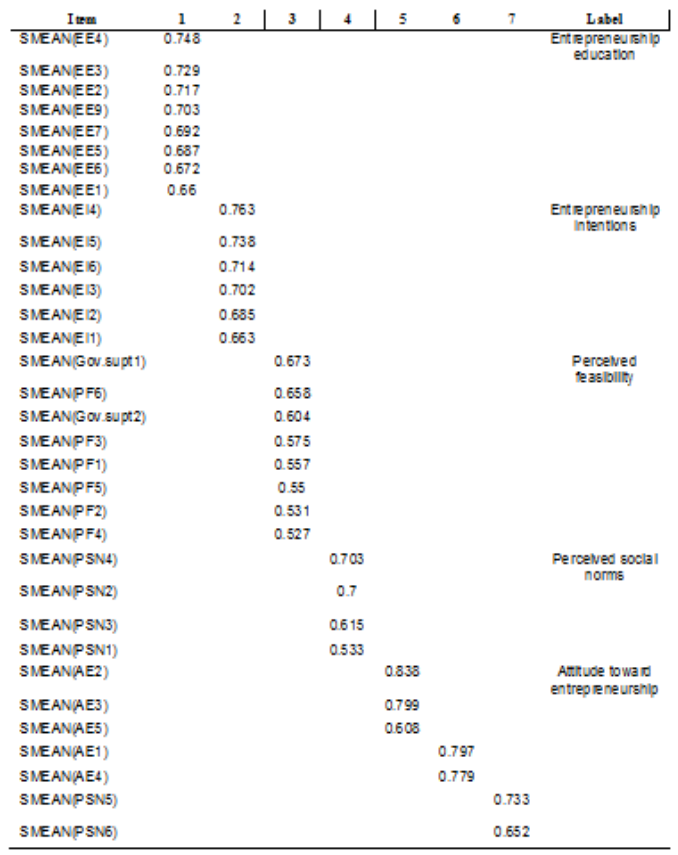

\subsection{Correlation Analysis}

Relationship between variables can be measured by using the correlation coefficient. The most common measurement used to find the relations among dependent and independent variables is the Pearson's correlation. Table 3 shows significant correlation between the variables.

Table 3. Correlation Analysis

\begin{tabular}{|l|r|r|r|r|r|r|r|}
\hline & MATT & MPSN & MPF & MEI & MEE & MGOV & MPSD \\
\hline MATT & 1 & - & - & - & - & $-.134^{*}$ & $.782^{* *}$ \\
& & $.259^{* *}$ & $.337^{* *}$ & $.299^{* *}$ & $.308^{* *}$ & & \\
MPSN & & 1 & $.299^{* *}$ & $.253^{* *}$ & $.316^{* *}$ & $.438^{* *}$ & $.395^{* *}$ \\
MPF & & & 1 & $.431^{* *}$ & $.482^{* *}$ & $.417^{* *}$ & $-.134^{*}$ \\
MEI & & & & 1 & $.461^{* *}$ & $.256^{* *}$ & -.117 \\
MEE & & & & & 1 & $.262^{* *}$ & -.090 \\
MGOV & & & & & & 1 & $.150^{*}$ \\
MPSD & & & & & & & 1 \\
\hline
\end{tabular}

**. Correlation is significant at the 0.01 level (2-tailed).

*. Correlation is significant at the 0.05 level (2-tailed). 
Entrepreneurship education (EE), perceived social norms(PSN), Attitude toward entrepreneurship(ATT), government support(GOV), perceived feasibility $(P F)$, entrepreneurial intention(EI).

\subsection{Regression Analysis}

\subsubsection{Hypotheses Testing}

\subsection{Testing Hypotheses $\mathrm{H} 2 \mathrm{~T}, \mathrm{H} 2 \mathrm{~b}, \mathrm{H} 2 \mathrm{c}, \mathrm{H} 2 \mathrm{~d}$}

Table 5: Regression Analysis

\begin{tabular}{|c|c|c|c|c|}
\hline \multicolumn{5}{|c|}{ Table 5: Regression Analysis } \\
\hline $\begin{array}{l}\text { Independent } \\
\text { Variable }\end{array}$ & $\begin{array}{c}\text { Dependent } \\
\text { Variable }\end{array}$ & $\beta$ & $\begin{array}{c}\text { T- } \\
\text { Value }\end{array}$ & $\begin{array}{c}\text { P- } \\
\text { Value }\end{array}$ \\
\hline MEE & MEI & 0.461 & 8.338 & $0.000 *$ \\
\hline MEE & MATT & -.308 & -5.188 & $0.000 *$ \\
\hline MEE & MPSN & 0.316 & 5.345 & $0.000 *$ \\
\hline MEE & MPF & 0.482 & 8.818 & $0.000 *$ \\
\hline MEE & MGOV & 0.262 & 4.36 & $0.000 *$ \\
\hline MATT & MEI & -.299 & -5.019 & $0.000 *$ \\
\hline MPSN & MEI & 0.253 & 4.195 & $0.000 *$ \\
\hline MPF & MEI & 0.431 & 7.658 & $0.000 *$ \\
\hline MGOV & MEI & 0.256 & 4.245 & $0.000 *$ \\
\hline \multicolumn{5}{|c|}{$\begin{array}{l}* \mathrm{p} \leq 0.001 \\
\mathrm{MEE}=\text { Entrepreneurship Education, MPSN= Perceived } \\
\text { Social Norms, MATT=Attitude toward Entrepreneurship, } \\
\text { MGOV=Perceived Government Support, MPF= } \\
\text { Perceived Feasibility, MEI= Entrepreneurial Intention. }\end{array}$} \\
\hline
\end{tabular}

The regression analysis as presented in the table 6 was performed to testing hypotheses H1a, H1b, H1c, and H1d to investigate the impact of entrepreneurial education on perceived desirability, perceived feasibility and the perceived governmental support for entrepreneurship. The results showed a significance relationship between entrepreneurship education (MEE) as independent variable and entrepreneurial intentions (MEI) as dependent variable $(t=8.338, \beta=0.461, p<0.05)$ this result is consistent with other studies such as Hussain and Norashidah (2015). The results also show a significant relationship between entrepreneurship education (MEE) and perceived feasibility (MPF), $(\mathrm{t}=8.818, \beta=0.482, \mathrm{P}<0.05)$. This means that the students perceive the entrepreneurship education has helped them to gain basic skills and knowledge that are essential to become entrepreneurs. The results also show a significant relationship between entrepreneurship education and perceived government support $(\mathrm{t}=4.36, \beta=0.262, \mathrm{P}<0.05)$. It is believed that many students have become aware of various schemes and funds offered by the government only after studying the entrepreneurship course. While entrepreneurship education has a positive impact on the students' perceived desirability for entrepreneurship, the results of this study showed that there was a negative relation between entrepreneurship education (MEE) and students personal attitudes (MATT) $(\mathrm{t}=-5.188-, \beta=-0.308-, \mathrm{p}<0.05$ ).

Findings showed that entrepreneurial intention as dependent variable has a significant relationship with independent variables; perceived social norms $(\mathrm{t}=4.195, \beta=0.253, \mathrm{P}<0.05)$ that means getting support from the society and family increases the entrepreneurial intentions; with government support $(\mathrm{t}=4.245, \beta=0.256, \mathrm{P}<0.05)$, students are encouraged to be entrepreneurs in future if they get support from the government they feel more secured; with perceived feasibility $(\mathrm{t}=7.658$, $\beta=0.431, \mathrm{P}<0.05)$, but it has negative relationship with attitude toward entrepreneurship $(\mathrm{t}=-5.019-, \beta=-0.299-, \mathrm{P}<0.05)$ which mean that if the attitude toward entrepreneurship is high does not mean the entrepreneurial intention is high.

\section{Results}

Entrepreneurship education has become an indispensable part of higher education curricula. It has been introduced in universities and colleges across programs in order to equip graduates with basic knowledge and skills in entrepreneurship and develop their attitudes and entrepreneurial intentions. The present study is an attempt to study the impact of entrepreneurial education on the entrepreneurial intentions of undergraduate students in a university in Oman. 
The results of the study show that the entrepreneurial intentions of the students across the studied sample (represented by the students from all the Colleges of the University) are somewhat high. While these results are consistent with others studies conducted in Oman (Segumpan and Zahari, 2012; Al-Harrasi and Al-Salti, 2014; Ibrahim et al., 2017; Bilal and Hussien, 2019; Amma and Fahad, 2013; Bakheet, 2018) which indicated positive entrepreneurial intention among Omani students, the results however contradict with the results of a study by Ibrahim et al. (2017) indicating, even when the Omani students have positive attitudes towards entrepreneurship they have low willingness to become entrepreneurs. The study revealed that entrepreneurship education has a significant positive impact on the students' feasibility of entrepreneurship. It showed that while there is a significant positive impact of entrepreneurship education on students' perceived social norms for entrepreneurship, at the same time the study revealed a negative impact of entrepreneurship education on students' attitudes towards entrepreneurship. Thus, the hypothesis that entrepreneurial education has a positive impact on students' desirability for entrepreneurship can be partially accepted. Furthermore, the study revealed that because of they studied a course on entrepreneurship they became aware of the governmental support for entrepreneurship and consequently enhanced their intentions to choose entrepreneurship as their career. This finding is significant as it indicates that the governments need to promote their entrepreneurship support programs aggressively to enhance the entrepreneurial motivation among the Country's youth. Conclusively, the findings suggest entrepreneurship desirability, feasibility and overall intentions can be leveraged through the entrepreneurship education.

Though the study chose to use a total population (full student cohort registered for MNGT100 during Fall 2019), only $72.14 \%$ participated in the survey which restricts the validity of the results. Also, the study considered the students studying this specialized course in only one University which limits the findings of this study to only one institution. Further research can be conducted for validation and generalization of these results.

\section{References}

Ajzen, I. (1991). The theory of planned behavior. Organizational Behavior and Human Decision Processes, 50(2), $179-211$. Al-Harrasi, A. S., \& Al-Salti, Z. S. (2014). Entrepreneurial intention among information systems (IS) students at Sultan Qaboos University: an exploratory study. Global Journal of Management and Business Research, 14(9).

AlMaimani, J., \& Johari, F. B. (2015). Enhancing active participation of SMEs and Islamic Banks towards economic diversification in Oman. Procedia Economics and Finance, Elsevier, 31, 677-688.

Amma, V. T., \& Fahad, H. (2013). What young presume about entrepreneurship? A Case of university students in Oman. ASBBS Proceedings, 20(1), 756-773.

Anderson, A. and Jack, S. (2008). Role typologies for enterprising education: the professional artisan? Journal of Small Business and Enterprise Development, 15 (2), 259-73.

Ashrafi, R., \& Murtaza, M. (2008). Use and impact of ICT on SMEs in Oman. Electronic Journal of Information Systems Evaluation, 11(3), 125-138.

Bakheet, A. H. (2018). Relationship between Attitudes and Intentions of Business Start-Up: A case of Omani University \& College Students. Academy of Entrepreneurship Journal, 24(2).

Bann, C. L. (2009). An innovative view of the entrepreneur through exploration of the 'lived experience' of the entrepreneur in startup of the business. The Journal of Business and Economic Studies, 15(2).

El-Gohary, H, O'Leary, S and Radway, P. (2012). Investigating the impact of entrepreneurship online teaching on science and technology degrees on students attitudes in developing economies: the case of Egypt. International Journal of Online Marketing, 2(1), 29-45.

Fayolle, A., \& Gailly, B. (2015). The impact of entrepreneurship education on entrepreneurial attitudes and intention: hysteresis and persistence. Journal of Small BusinessMmanagement, 53(1), 75-93.

Fretschner, M., \& Weber, S. (2013). Measuring and understanding the effects of entrepreneurial awareness education. Journal of Small Business Management, 51(3), 410-428.

George, D., \& Mallery, P. (2003). SPSS for windows step by step: A simple guide and reference. 11.0 update (4th ed.). Boston: Allyn \& Bacon.

Gerba, D. T. (2012). Impact of entrepreneurship education on entrepreneurial intentions of business and engineering students in Ethiopia. African Journal of Economic and Management Studies, 3(2), 258-277.

Greene, P. G., Brush, C. G., Eisenman, E. J., Neck, H., \& Perkins, S. (2015). Entrepreneurship education: A global consideration from practice to policy around the world. Executive summary of the 2015 WISE Research Report. Qatar Foundation.

Hattab, H. W. (2014). Impact of entrepreneurship education on entrepreneurial intentions of university students in Egypt. The Journal of Entrepreneurship, 23(1), 1-18.

Hussain, A., \& Norashidah, D. (2015). Impact of entrepreneurial education on entrepreneurial intentions of Pakistani Students. Journal of Entrepreneurship and Business Innovation, 2(1), 43-53.

Ibrahim, O. A., Devesh, S., \& Ubaidullah, V. (2017). Implication of attitude of graduate students in Oman towards entrepreneurship: an empirical study. Journal of Global Entrepreneurship, 7:8, 1-17. 
Jones, C.; English, J. (2004), A contemporary approach to entrepreneurship education. Education + Training, 46(8/9), 416423.

Kalyoncuoğlu, S., Aydıntan, B., \& Göksel, A. (2017). The effect of entrepreneurship education on entrepreneurial intention: an experimental study on undergraduate business students. Journal of Management Research, 9(3), 72-91.

Keat, O. Y., Selvarajah, C., \& Meyer, D. (2011). Inclination towards entrepreneurship among university students: an empirical study of Malaysian university students. International Journal of Business and Social Science, 2(4), 206-220.

Krueger, N. (1993). The impact of prior entrepreneurial exposure on perceptions of new venture feasibility and desirability. Entrepreneurship Theory and Practice, 18(1), 5-21.

Krueger, N., Hansen, D. J., Michl, T., \& Welsh, D. H. (2011). Thinking "sustainably": the role of intentions, cognitions, and emotions in understanding new domains of entrepreneurship. In Lumpkin, G. and Katz, J. (Ed.). Social and Sustainable Entrepreneurship, 3, 275-309

Lee, L., Wong, P. K., Der Foo, M., \& Leung, A. (2011). Entrepreneurial intentions: the influence of organizational and individual factors. Journal of Business Venturing, 26(1), 124-136.

Lekhanya, L. M. (2016). Critical Analysis of Entrepreneurial Spirit, Attitudes and Perceptions of Young South Africans in KwaZulu-Natal province. Problems \& Perspectives in Management, 14(3), 179-183

Liñán, F. (2004). Intention-based models of entrepreneurship education. Piccola Impresa/Small Business, 3(1), 11-35.

Liñán, F., Rodríguez-Cohard, J. C., \& Rueda-Cantuche, J. M. (2011). Factors affecting entrepreneurial intention levels: a role for education. International Entrepreneurship and Management Journal, 7(2), 195-218.

Malebana, M. J., \& Swanepoel, E. (2014). The relationship between exposure to entrepreneurship education and entrepreneurial self-efficacy. Southern African Business Review, 18(1), 1-26.

Naktiyok, A., Karabey, C. N., \& Gulluce, A. C. (2010). Entrepreneurial self-efficacy and entrepreneurial intention: the Turkish case. International Entrepreneurship and Management Journal, 6(4), 419-435.

Olorundare, A.S., \& Kayode, D.J. (2014). Entrepreneurship education in Nigerian universities: A tool for national transformation. Asia Pacific Journal of Educators and Education, 29, 155-175.

Ramalan, R.\& Ngah, S. (2012). Teaching entrepreneurship at Universiti Kuala Lumpur- British Malaysian Institute: the students' perception and mindset. International Journal of Future Computers and Communication, 1(3), 242-244.

Sánchez, J. C. (2011). University training for entrepreneurial competencies: Its impact on intention of venture creation. International Entrepreneurship and Management Journal, 7(2), 239-254.

Segumpan, R. G., \& Zahari, J. S. A. (2012). Attitude towards entrepreneurship among Omani college students trained in business. International Journal of Business and Behavioral Sciences, 2(4), 61-72.

Sesen, H. (2013). Personality or environment? A comprehensive study on the entrepreneurial intentions of university students. Education + Training, 55(7), 624-640.

Shapero, A., \& Sokol, L. (1982). The social dimensions of entrepreneurship. Encyclopedia of Entrepreneurship, 72-90.

Veciana, J. M., Aponte, M., \& Urbano, D. (2005). University students' attitudes towards entrepreneurship: A two countries comparison. The International Entrepreneurship and Management Journal, 1(2), 165-182.

Wang, Y. \& Verzat, C. (2011). Generalist or specific studies for engineering entrepreneurs?: Comparison of French engineering students' trajectories in two different curricula. Journal of Small Business and Enterprise Development, $18(2), 366-383$

Welsh, D. H., Tullar, W. L., \& Nemati, H. (2016). Entrepreneurship education: Process, method, or both?. Journal of Innovation \& Knowledge, 1(3), 125-132.

Young, J. (1997), "Entrepreneurship education and learning for university students and practicing entrepreneurs", in Sexton, D. and Smilor, R. (Eds), Entrepreneurship 2000, 215-242.

Zhang, Y., Duysters, G., \& Cloodt, M. (2014). The role of entrepreneurship education as a predictor of university students' entrepreneurial intention. International Entrepreneurship and Management Journal, 10(3), 623-641. 